\title{
IN SEARCH OF LOST LATIN-AMERICAN COLOURS: AN ANALYSIS OF THE CONSTITUTIONAL PROTECTION OF LGBTI RIGHTS IN LATIN AMERICA
}

\begin{abstract}
This study investigates the constitutional protection of LGBTI rights in South America and Mexico. Under the theoretical framework of Nancy Fraser's postwestphalian democratic justice, it questions whether the constitutional protection of these rights in such countries is satisfactory in order to move forward towards the accomplishment of justice to LGBTI persons. The research conducts an empirical study and undertakes a qualitative analysis using the techniques of literature review, documental analysis, and survey. Among the results, it was determined that only two of the analysed constitutions expressly prohibits both sexual orientation - and gender identity-based discrimination. Only one of them uses gender-neutral language in the provision regarding civil union and, therefore, enables the union between two people of the same gender. Under another perspective, the answers of the majority of the Latin-American organizations in the survey indicated that the constitutional protection of LGBTI rights is unsatisfactory in their countries. Therefore, after the analysis of all the data obtained in the research, it was possible to conclude that the constitutional protection is precarious and does not guarantee the most basic rights to LGBTI population.
\end{abstract}

\section{Keywords}

comparative constitutional law - LGBTI rights - Latin-American constitutionalism social movements - sexual orientation - gender identity

* Lawyer. Master candidate at Pontifical Catholic University of Rio de Janeiro (PUCRio). 


\section{INTRODUCTION}

In search of lost time, by Marcel Proust, ${ }^{1}$ was one of the first literary productions to focus explicitly on the dilemmas of homosexuality; and, according to some interpretations, even transgender issues. That is why it became an inspiration for the title of this paper. Although the discourse used by the author may be the subject of several criticisms, the representative role played by the novelist's writings is undeniable. The narrative, especially regarding the character of the Baron de Charlus, enables the reader to identify one of the most recurrent forms of violence experienced by lesbians, gays, bisexuals, trans, and intersex (LGBTI) persons ${ }^{2}$ : the violence of the closet $^{3}$. Despite significant achievements, many of these people, under the fear and guilt created by society, are forced to hide their true condition, sometimes even from themselves, limiting their freedom and their full existence as human beings. It is an

1 Proust, Marcel. Em busca do tempo perdido: Sodoma e Gomorra - volume quatro. São Paulo: Globo, 2008.

2 The use of the acronym "LGBTI" represents only one of the possibilities, within a very diverse universe of acronyms to represent this sector of the population. Its use is not intended to exclude any other forms of identity or sexuality that are not directly encompassed by its letters. Its application was defined precisely because it is considered to be one of the most inclusive forms of referring to the diverse members of this population. In addition, in coherence with the theoretical framework adopted, it is understood to be closer to a transformative remedy, as will be seen later, when using an acronym with a lower number of letters and yet representing a great diversity of individuals; such as using the letter " $\mathrm{T}$ " and the word "trans" to refer to the various members of the trans population. This is because the smaller number of categorizations implies less differentiation, stigmatization, and hierarchization of identities, thus, destabilizing and deconstructing the establishment of standards and allowing the recognition of more fluid identities, without erasing certain specificities.

3 The word "closet" is used here, and in the rest of this paper, metaphorically. It represents, as constructed by Sedgwick, the oppression experienced by LGBTI, condemned to hide their sexuality or gender identity. Moreover, even if they do not want to hide it, they are obliged to reveal it daily, at each new environment they attend to, because of the presumption of heterosexuality and cisgender identity in our society. See: Sedgwick, Eve Kosofsky. Epistemology of the closet. Berkeley and Los Angeles: University of California Press, 2008. 
oppression invariably suffered by LGBTI in several, if not all, the days of their lives. But it is not the only one.

Sexual orientation and gender identity that are seen as deviant are used to discriminate against LGBTI, preventing them from accessing the most basic civil, political, economic, social, and cultural rights. Only in 1990, the World Health Organization (WHO) removed homosexuality from the International Classification of Diseases (ICD). Still in 2019, transsexuality remains inserted in this classification ${ }^{4}$. It was merely withdrawn from the chapter of mental disorders, reallocated in the section on "conditions relating to sexual health".

Moreover, LGBTI still face daily physical and symbolic violence. They are harmed and murdered for no reason other than their own condition. They are condemned for being born and for sustaining their existence, for believing that they are free to love and express themselves. All these factors motivated the beginning of this research.

An initial concern revolved around how justice could be achieved for LGBTI people, and how to ensure dignity for their lives. However, this is an extremely complex dilemma and cannot be solved unless by exploring its ramifications in several other dilemmas. And that is what this article seeks to do: to advance in the investigation of one of the many dimensions that involve this greater problem. In this sense, adopting as a theoretical framework the theory of postwestphalian democratic justice, proposed by Nancy Fraser, the central question of this article asks whether the constitutional protection of LGBTI rights in Latin America is satisfactory. The initial hypothesis, based on the recorded numbers of assaults and assassinations committed against these persons, indicates that the protection would be insufficient, because it could not protect them from such events.

${ }^{4}$ It should be noted that, in the case of trans people, the discussion about depathologization should take into account the different realities and contexts. This is because, as Berenice Bento points out, in many countries access to gender affirming surgery and hormonal treatment depends on the classification of trans identity as a disease. Thus, the struggle for depathologization must always be accompanied by the recognition of surgery and hormonal treatment as fundamental rights (derived from the right to health) of trans persons, which must be provided free of charge by the State. See: Bento, Berenice. "Na Escola se Aprende Que a Diferença faz a Diferença". Revista Estudos Feministas 19, no. 2 (2011): 549-559. 
In order to test the hypothesis, it was followed by a juridicalcomprehensive type of investigation. According to Gustin and Dias, ${ }^{5}$ this modality of research consists in the decomposition of the legal problem at various levels for its in-depth study. In this sense, the analysis of the problem was divided into two aspects: 1) the normative constitutional provision of rights for LGBTI; 2) the LGBTI movement's perception of the constitutional protection and concretization of their rights. Judicial decisions were excluded from the examination because it is considered that the absence of provision in the constitutional text already demonstrates a protective insufficiency ${ }^{6}$, since a written constitutional clause establishing those rights is essential for the realization of its symbolic value, as well as for the guarantee of greater legal certainty.

In addition, an imaginative approach to comparative law was adopted, as proposed by Geoffrey Wilson. ${ }^{7}$ According to the author, unlike traditional comparative law, which limits itself to comparing texts and legal systems for their better understanding, an approach that uses an "informed imagination" is not limited to traditional methods nor to what is formally designated as law. Therefore, it is concerned with the social aspects of research. In this sense, we also highlight the markedly interdisciplinary character of this work, adopting a bibliography that includes not only legal texts, but also writings from psychology, philosophy, sociology, politics, history, linguistics, and literature.

For the development of the investigation, the techniques of literature review, documental analysis, and survey were applied. An empirical research of eminently qualitative character was conducted, although on some occasions quantitative elements were also emphasized. The literature review was used to better understand the theoretical framework adopted, as well as to obtain secondary data regarding the protection of LGBTI rights. In turn, the documental analysis consisted in examining the

${ }^{5}$ Gustin, Miracy Barbosa de Sousa, and Maria Tereza Fonseca Dias. (Re)pensando a pesquisa jurídica: teoria e prática. Belo Horizonte: Del Rey, 2013.

${ }^{6}$ This is especially important in civil law legal systems such as the ones that have been analysed in this research.

7 Wilson, Geoffrey. "Comparative Legal Scholarship". In Research Methods for Law, eds. Mike Mcconville and Wing Hong Chui (Edinburgh: Edinburgh University Press, 2007), 87-103. 
constitutions from all South American countries and Mexico, in the search for the protection of specific rights regarding LGBTI persons. Finally, the survey, directed to Latin American organizations that work with LGBTI issues, made it possible to capture the opinion of the movement about the constitutional protection of their rights, favouring a bottom-up legal approach.

Thus, the overall objective of the work was to discover the extent and form of the constitutional protection of LGBTI rights in South America and Mexico. In addition, the research had as specific objectives: 1) the realization of a wide literature review on theories of justice and recognition; as well as the revision and careful readings of texts on constitutional interpretation, queer theory, Latin American constitutionalism, and LGBTI rights; 2) the reading and examination of all the constitutions from South American countries and from Mexico; 3) the application of a survey to LGBTI organizations located in Latin America, and its subsequent analysis.

For a better exposition of the research conducted, this article is divided into three sections. In the first section, the theoretical framework is explored while the second section is dedicated to the analysis of the first part of the empirical data collected. In this sense, the segment is devoted entirely to the demonstration of the criteria applied in the analysis of constitutional texts, as well as the results obtained from this examination. Finally, the third section is dedicated to the analysis of the survey's answers. Thus, the method used in the selection of the sample and, later, the methodology applied in the examination of the answers are highlighted.

\section{The Theory Of Postwestphalian DEMOCRATIC JUSTICE}

As previously mentioned, the theoretical framework chosen to guide the analysis of the data is Nancy Fraser's postwestphalian theory of democratic justice. Thus, this section intends to provide a brief overview of her theory, in order to facilitate further analysis in the development of the article. 
A philosopher dedicated to themes such as justice and democracy, Nancy Fraser elaborated a three-dimensional theory that includes three levels for the realization of justice, accomplishing parity of participation: economic, cultural, and political. Initially designed only with the first two facets, the political dimension was recently elevated to an autonomous category, responding to the anxieties caused by the current stage of globalization. ${ }^{8}$

In this way, each of these dimensions has its corresponding levels of justice and injustice. Economic injustice is materialized through maldistribution; cultural, by misrecognition; and the political is embodied in misrepresentation. As the author points out, these three aspects are essential to understanding the means for achieving justice. Although in certain contexts one can perceive the prevalence of some of the types of injustice, it is necessary to consider that the three form an interdependent set, neither layer being able to be reduced to the injustice generated by the other. ${ }^{9}$

The economic dimension of justice is represented by the idea of the distribution of goods, resources, and wealth that generates class differences and promotes the exploitation of labour in the capitalist world. Examples of this level of injustice are: the economic exploitation of workers by companies which profit from the work of a certain segment of the population, and the denial to certain people of the enjoyment of the material goods offered by the market, which, in many cases, were produced precisely by themselves as workers. ${ }^{10}$

As mentioned, the second dimension responsible for the realization of justice is the cultural one, in which the demands for the recognition of each of the despised groups are framed. In this way, Fraser proposes an approach based on the conceptualization of recognition as a matter of social status. From this criterion, misrecognition would translate as a form of social subordination. In this sense, the concept is related to the

${ }^{8}$ Fraser, Nancy. Scales of Justice: reimagining political space in a globalizing world. New York: Columbia University Press, 2010.

9 Fraser, Nancy. "From Redistribution to Recognition? Dilemmas of justice in a 'postsocialist' age". In Adding Insult to Injury: Nancy Fraser debates her critics, ed. Kevin Olson (London: Verso, 2008), 11-41.

10 Ibid. 
institutionalized reproduction of subordination patterns that prevent the participatory parity of certain individuals in social life. Hence, the institutional factor is essential for the characterization of the injustice of misrecognition, which will happen through the stigmatization of certain people as inferior, excluding them from (and invisibilizing them in) social interaction. ${ }^{11}$

One of the most pressing possibilities of this institutionalization is the legal-normative field. In this sense, laws that categorize certain social actors as inferior or transgressors (as opposed to others, which would be within the social norm) provoke the subordination of status. Nonetheless, this also occurs when legislation, disregarding the very possibility of existence of certain individuals (positioning them as non-beings), fails to consider them in the normative edition, creating gaps that prevent their participation in social life. As an example, a law prohibiting marriage between people of the same gender participates in this kind of injustice; however, so does the law that regulates only heterosexual unions, ignoring the very existence of other family arrangements and remaining silent about them.

Fraser points out that the root of injustice against gays and lesbians (the despised sexualities) would be in the cultural dimension, given that it reproduces itself through institutionalized and reiterated social patterns, not through division of labour ${ }^{12}$. For this reason, she characterizes homophobia as the "cultural devaluation of homosexuality"13, while heterosexism would be the reassertion of heterosexual privileges through the issuance of norms that impose them. Such a situation is easily discernible through the innumerable rights denied to this group, as well as the frequent social situations in which these sexualities are subjected to discrimination, violence, harassment, and humiliation. For this reason, Fraser points out that "overcoming homophobia and heterosexism requires a change in the order of sexual status, de-institutionalizing the

${ }^{11}$ Fraser, Nancy. "Rethinking Recognition". New Left Review 3 (May-June 2000): 107-120.

12 Fraser, Nancy. "From Redistribution to Recognition? Dilemmas of justice in a 'postsocialist' age". In Adding Insult to Injury: Nancy Fraser debates her critics, ed. Kevin Olson (London: Verso, 2008), 11-41.

${ }^{13}$ Ibid, at 21. 
heteronormative patterns of value, replacing them with patterns that express equal respect for gays and lesbians". ${ }^{14}$

Finally, having analysed the cultural and economic aspects of justice, we can move to the last of Fraser's dimensions: the political. According to the author, the political dimension serves as a stage for the claims for redistribution and recognition to be debated and demanded. In this sense, it is responsible for establishing the procedures through which such demands may legitimately be conveyed.

The realization of political justice occurs through representation. The injustice in this dimension is therefore that of misrepresentation. In this respect, Fraser distinguishes between three levels of political injustice: the first, related to the ordinary-political misrepresentation, covering already known issues regarding electoral rules; the second linked to what she called a misframing, referring to the borders of politics and justice itself, which can be identified in discussions, for example, about the extent of a given jurisdiction ${ }^{15}$; and the third, related to "the failure to institutionalize parity of participation at the meta-political level"16, which is named meta-political misrepresentation.

In view of the reality of injustices, there are two possible remedies to the solution of inequality: affirmative or transformative. According to Fraser, affirmative remedies, in general, would be those aimed at correcting inequities with the instruments provided by the current system itself. That is, using the tools available within the structure that causes the injustice. This type of remedy clearly has a limited scope of action, since it does not intend to substantially alter the status quo, aiming at only a small advance in social reality. On the other hand, a transformative remedy seeks precisely the opposite: the correction of unequal results by restructuring the framework that generates them. ${ }^{17}$ Thus, while

${ }^{14}$ Fraser, Nancy. "Redistribuição, Reconhecimento e Participação: por uma concepção integrada de justiça". In Igualdade, Diferença e Direitos Humanos, eds., Daniel Sarmento, Daniela Ikawa and Flávia Piovesan (Rio de Janeiro: Lumen Juris, 2010), 167-189 at 173.

15 Fraser, Nancy. Scales of Justice: reimagining political space in a globalizing world. New York: Columbia University Press, 2010.

16 Ibid, at 26.

17 Fraser, Nancy. "From Redistribution to Recognition? Dilemmas of justice in a 'postsocialist' age". In Adding Insult to Injury: Nancy Fraser debates her critics, ed. Kevin Olson (London: Verso, 2008), 11-41. 
transformative remedies are ideal to end injustices in a long term, the affirmative ones are also necessary in a short-term basis, although their application is limited, and they are not able to completely eliminate inequalities.

Lastly, it must be highlighted that all of these dimensions of Fraser's theory, as well as the different types of remedies, will be essential to fully understand the analysis of the empirical data collected. That is the purpose of the next two sections.

\section{The Constitutional Protection OF LGBTI RIGHTS}

Epstein and King point to "replicability" as an essential rule to be observed by the researcher in empirical investigation. ${ }^{18}$ Thus, it is important to expose, in a detailed way, how the data used in the research was collected. In this sense, the authors point out that "good empirical work adheres to the pattern of replication: another researcher must be able to understand, evaluate, base on, and reproduce the research without the author providing any additional information." Therefore, this section is devoted to the explanation of the form of data collection performed in the documental analysis.

Initially, the study object was very broad: to analyse all Latin American constitutions, including those of the countries from South America, Central America (and the Caribbean), and Mexico. However, as the data was collected, we noticed that the defined object was extremely vast and that would prevent, because of time, a detailed and critical analysis of the information obtained. Thus, given the temporal and financial limitations of the investigation, it was decided to examine the constitutions of the countries from South America, as well as Mexico. The main reason for the choice of those countries is the understanding that their constitutional tradition is more similar to each other than to that of the Caribbean, in view of the composition of the so-called "New Latin-

18 Epstein, Lee and Gary King. Pesquisa empírica em direito: as regras de inferência. São Paulo: Direito GV, 2013 at 56. 
American Constitutionalism", even if not all of those countries are included in such a tradition.

Within this geographic framework, the analysis of the Falkland Islands, South Georgia and South Sandwich Islands, and French Guiana was also excluded. This is because the first two are under the jurisdiction of the United Kingdom, while the latter submits itself to the French legal system. In this way, since the objective is to draw a panorama of protection in Latin America, it is not adequate to examine its constitutional charters. Thus, Argentina, Bolivia, Brazil, Chile, Colombia, Ecuador, Guyana, Mexico, Paraguay, Peru, Suriname, Uruguay, and Venezuela remained in the list of countries to be investigated.

The text of each of these constitutions was obtained from official websites of the legislative or executive of those States or, when it was not available in these media, on the website of the Organization of American States (OAS). Access to these documents and its archiving were carried out between November $12^{\text {th }}$ and $18^{\text {th }}$ of 2017 . Therefore, only the constitutional amendments approved up to that period were considered.

Due to possible ambiguities or changes of meaning from translations, the texts were read in their original language. However, there is one exception. In view of the official language of Suriname, the Dutch language, and owing to the lack of mastery of this vernacular by this researcher, it was necessary to use a translated English version made available by Unesco. ${ }^{19}$

Regarding the method, the examination of the data was guided by a tripartite qualitative analysis of empirical documentation proposed by Mario Cardano. ${ }^{20}$ The analysis method proposed by the author includes the following steps: segmentation, qualification, and individuation of relations. Segmentation refers to the establishment of markers, "whose function is to identify relatively homogeneous segments to be subjected to comparison within empirical materials" ${ }^{21}$ In this sense, all the constitutions

19 This translated version can be found at: <http://www.unesco.org/education/ edurights/media/docs/dfcff4209dad7879549a7d46dc0bcbf82919c591.pdf>.

${ }_{20}$ Cardano, Mario. Manual de pesquisa qualitativa: a contribuição da teoria da argumentação. Petrópolis: Vozes, 2017.

${ }^{21}$ Ibid, at 273. 
were fully read in the search for the provision of specific rights, but guided by three criteria to be specially observed, forming the segmentation. These are: 1) the use of gender-inclusive language; 2) the prohibition against discrimination of LGBTI; 3) the possibility of civil union between persons of the same gender. In addition to the peculiar motives to each of these criteria, which will be explained later, the three were chosen because their presence (or absence) can be more easily perceived in the normative text.

Further, the qualification stage is conceptualized by Cardano as the "assignment of one or more properties to a given segment of empirical documentation, useful for its characterization". ${ }^{22}$ In this way, the technique allows one to deepen the analysis dimension of the document by means of its greater specification. Therefore, for the qualification of the segments, a "template analysis" was used as proposed by Nigel King. ${ }^{23}$ The method consists in the composition of an analytical grid from the characterization of the identified elements in order to enable its comparison. The use of template analysis can be based on two main approaches: inductive (datadriven), in which the grid is composed of categories that were observed in the analysis of the material, or deductive (theory-driven), in which the data found in the analysed document is allocated into predefined categories. In the examination of the constitutions, an inductive approach was applied in the segments related to non-discrimination and inclusive language (in the second, using textual absences as well) and a deductive approach in the case of civil union, observing a categorization previously established.

Finally, the individuation of relations consists of an analysis from the comparison of qualifications or even of the separation of a certain qualification for analysis. Thus, in this last stage, the analysis was performed through the cross-examination of the qualifications and also of the deviant cases, unravelling their distinction in relation to the others.

${ }^{22}$ Ibid, at 293.

${ }^{23}$ King, Nigel. "Doing Template Analysis". In Qualitative Methods in Organizational Research: core methods and current challenges, eds. Gillian Symon and Catherine Cassel (London: SAGE Publications, 2012), 426-450. 


\section{The USE of Gender-InCLusive Language IN THE CONSTITUTIONAL TEXT}

Daniel Borrillo has gone deeply into the study of homophobia ${ }^{24}$ and its various forms of manifestation. In his work, the author seeks to categorize some of the main types of expression of this prejudice, emphasizing the differentiations between irrational and cognitive homophobia and between general and specific homophobia. ${ }^{25}$ At this point, we are particularly interested in the author's idea of homophobia in its general perspective.

According to him, homophobic practices are intrinsically linked to the sexism that is deeply instilled in our society, through which roles of feminine and masculine are naturalized. That is, a sexual order that "implies both the subordination of the feminine to the masculine, and the hierarchy of sexualities". ${ }^{26}$ In this way, homophobia, in its most general aspect, would be the product of the sexist pattern, which harasses those who do not fit the expression of their assigned gender, male or female. Thus, gays and lesbians, by assuming some of the characteristics of the originally opposing gender (such as sexual desire) break this barrier, which provokes social disapproval. Even more bold, under the sexist logic, are trans and intersex people who effectively transgress, completely, the norm that crates a gendered society.

In this sense, if one of the forms of externalization of prejudice against LGBTI is sexism, it would be coherent to think that those societies - in this case represented by their legal systems - that are more advanced in the fight against gender inequality, would also be closer to recognizing rights of LGBTI persons.

For this reason, the use of gender-inclusive language in the constitutional text was adopted as one of the criteria to be analysed. It is important to note that the adoption of this type of language demonstrates

${ }^{24}$ The author's idea of homophobia intends to encompass all forms of LGBTIphobic prejudice.

${ }^{25}$ Borrillo, Daniel. Homofobia: história e crítica de um preconceito. Belo Horizonte: Autêntica Editora, 2016.

${ }^{26}$ Ibid, at 30 . 
an even greater commitment to overcoming the gender inequality barrier than the mere provision of rights for women, for example. This is because it implies a change in the rooted linguistic structure that historically values male predominance, especially in languages of Latin origin. There are numerous legislations that provide specific rights for women. Few, however, are those that allow the breaking of the language barrier, which daily exercises symbolic violence over them.

Also worthy of attention is the fact that the criterion chosen is the observance or not of a gender-inclusive language. And not of a genderneutral language. An inclusive language still uses gender markers, but always demarcating both the masculine and feminine genders. On the other hand, gender-neutral language would require a much greater subversive effort from the legislator, which, of course, was not found in any of the texts. This second modality would require the total abstention of using traditional markers of feminine and masculine. That is, the use of only terms that do not have this designation (such as "people") or the replacement of traditional markers with a single alternative (such as using the " $\mathrm{x}$ " or " $\mathrm{e}$ " in words) $)^{27}$.

In this way, it is highlighted that, despite being a great advance, inclusive language is not the ideal final level. This is because, although it solves the linguistic subordination of feminine to masculine, it still maintains a binary logic, excluding all other forms of gender expression that do not fall into these categories.

In view of these observations, it is pointed out that the objective at this moment was to identify whether there is any relation between the use of gender-inclusive language (which represents the advance of overcoming inequality between men and women) and the protection of LGBTI rights. The hypothesis was that an order with a high degree of evolution (to the point of modifying the language used) would also be more sensitive to the themes of sexual orientation and gender identity.

In order to verify the conformity of this hypothesis, the rules of inference defined by Epstein and King were followed, more specifically in the attempt to establish a causal inference. According to the authors, inference is the "process of using facts that we know to learn about the

${ }^{27}$ Once again, this is of special relevance when concerning languages of Latin origin. 
facts that we do not know" ${ }^{28}$ The causal inference, in turn, consists of the same process by the conjugation of two different variables: a dependent variable (which would be, in the present case, the advance in the protection of LGBTI rights, represented by the fulfilment or not of the civil union and the non-discrimination criteria) and a main variable (which in this case would be the advance in combating gender inequality, represented by the use of gender-inclusive language). Thus, the correspondence of the causal effect occurs through the analysis of whether the insertion or withdrawal of the main variable causes any change in the dependent variables. In our context, it is to say: whether the use of gender-inclusive language by the Constitution leads to the provision of rights to the LGBTI population as well.

This criterion was assessed through the use of the two gender designations, for example, "his and hers", "he and she", instead of only "his" or "he".

After this examination, it was identified that only $30.77 \%$ of the investigated constitutions adopted this language modality. This corresponds to a total of four countries. They are: Bolivia, Ecuador, Guyana, and Venezuela. Subsequently, for testing the initial hypothesis, this was combined with the other analysis criteria (prohibition of discrimination and the possibility of civil union). Thus, trying to detect if, as expected, these four countries would also have a positive result in the two other parameters.

Unfortunately, that was not what happened. As shown in Table 1, of the four countries, only the constitutional charters of Bolivia and Ecuador have provisions that prohibit discrimination against LGBTI.

In addition, the Constitutions of the three Latin-speaking countries expressly provide that marriage is between "a man and a woman" (or vice versa). This framework is repeated in the clause regarding "stable union", with the exception of the Ecuadorian Constitution, which, in this second type of civil union, identifies that it would be a relationship between "persons".

${ }^{28}$ Epstein, Lee and Gary King. Pesquisa empírica em direito: as regras de inferência. São Paulo: Direito GV, 2013 at 47. 
Table 1. Relation of Constitutional Protection of LGBTI Rights among Countries that Adopt Gender-Inclusive Language

\begin{tabular}{|c|c|c|c|}
\hline \multirow{2}{*}{ Country } & \multirow{2}{*}{$\begin{array}{l}\text { Prohibition of } \\
\text { Discrimination } \\
\text { Against LGBTI }\end{array}$} & \multicolumn{2}{|l|}{ Civil Union } \\
\hline & & Marriage & $\begin{array}{l}\text { Stable Union } \\
\text { ("uniones de hecho") }\end{array}$ \\
\hline Bolivia & $\begin{array}{l}\text { Yes (based on sexual } \\
\text { orientation and } \\
\text { gender identity) }\end{array}$ & $\begin{array}{l}\text { Between "una } \\
\text { mujer y un } \\
\text { hombre" }\end{array}$ & $\begin{array}{l}\text { Between "una mujer } \\
\text { y un hombre" }\end{array}$ \\
\hline Ecuador & $\begin{array}{l}\text { Yes (based on sexual } \\
\text { orientation, gender } \\
\text { identity and HIV } \\
\text { status) }\end{array}$ & $\begin{array}{l}\text { Between } \\
\text { "hombre y } \\
\text { mujer" }\end{array}$ & $\begin{array}{l}\text { Between "dos } \\
\text { personas" }\end{array}$ \\
\hline Guyana & No & $\begin{array}{l}\text { Without } \\
\text { regulation }\end{array}$ & Without regulation \\
\hline Venezuela & No & $\begin{array}{l}\text { Between "un } \\
\text { hombre y una } \\
\text { mujer" }\end{array}$ & $\begin{array}{l}\text { Between "un hombre } \\
\text { y una mujer" }\end{array}$ \\
\hline
\end{tabular}

In the case of Guyana, although there is no constitutional regulation of the civil union, the juridical system is even more drastic in rejecting any form of relationship between persons of the same gender. The country's legislation opted for the criminalization of homosexual conduct or, more specifically, gay, since the legal device refers notably to the interaction between two men.

Thus, it is clear that, despite the advancement of this legal framework in relation to the reduction of gender inequality, the scenario for the LGBTI population is devastating. Unlike most cases, homosexual relationships are repressed, not only in the public sphere, but also in the private one. In addition, it was decided to carry out such repression through the criminal law, which aggravates its character, criminalizing the existence of these individuals. Gays and bisexuals are forbidden to love and relate, have all their dignity withdrawn and can be punished with life imprisonment for something inherent to their own existence. Something that cannot be voluntarily altered: their sexuality, their desire for other human beings. 
In fact, the hypothesis initially suggested was not demonstrated concretely, and it was not possible to draw the intended inference. In other words, there does not seem to exist a necessary relationship between advancing the fight against gender inequality and providing specific rights for LGBTI. However, the opposite reasoning is corroborated by the data. The two countries whose constitutional protection of LGBTI has been shown to be the most comprehensive and advanced (as will be further examined later) are also two legal systems that adopt genderinclusive language in their constitutional text: Ecuador and Bolivia. Therefore, if the advancement in women's rights does not presuppose that the same legal system will be sensitive to issues of sexual orientation and gender identity, on the other hand, the advance in LGBTI issues occurs in legal orders in which there is already a consolidation, at least textual, of specific rights for women, attenuating gender inequality. It should be noted, however, that such inference should not be taken categorically, but merely as an illustrated tendency, given that the reduced sampling does not permit any categorical and generalized assertion.

\section{Prohibition of Discrimination Against LGBTI}

The second criterion chosen for the analysis of the documents was the presence or not of clauses that prohibit discrimination against the LGBTI population. The fundamental right to non-discrimination derives directly from the right to equality, being a necessary prerequisite for the realization and usufruct of all other individual guarantees, ensuring legal and social isonomic treatments. In this perspective, the prohibition of discrimination (in its arbitrary aspect) is the most basic of rights necessary to overcome injustices of recognition and representation, effecting parity of participation.

On this topic, Bandeira de Mello points out that "isonomy is enshrined as one of the greatest guiding principles of individual rights". ${ }^{29}$ Thus, without equality, there is no way to advance in the prediction of other

${ }_{29}$ Mello, Celso Antônio Bandeira de. O Conteúdo Jurídico do Princípio da Igualdade. São Paulo: Malheiros Editores, 2010 at 45. 
specific rights, which cannot be done without the safeguarding of nondiscrimination. It is precisely for this reason that this criterion was chosen: considering it as the starting point for deeper and more complete guarantees, since it is the founding (albeit precarious) level of other normative provisions that may focus on LGBTI persons.

As a starting point for the documental analysis, attempts were made to identify the mention of markers such as "sexual orientation" or "gender identity" (and its possible variants) among the list of reasons why a differential or discriminatory treatment is prohibited.

In the first examination of the constitutional charters, it was found that in only $23 \%$ of the countries is there express provision that prohibits, to some extent, discrimination against LGBTI. This corresponds to only three of the thirteen analysed constitutions, which is a very small number in the studied whole.

Nevertheless, the data collected deserves more careful and detailed treatment. In this sense, the constitutional provisions were divided into four categories, which are detailed in Table 2. The first one refers to the prohibition of discrimination based on both sexual orientation and gender identity. In the second category, there are provisions that prohibit discrimination based solely on sexual orientation. The third classification refers to texts that do not list any form of prohibition of discrimination related to LGBTI, although they do so in relation to other markers such as race and gender. Lastly, the fourth section refers to those countries whose constitutional texts have chosen not to define a list of situations where discrimination is prohibited or where there is no provision relating to such legal category.

It is important to note that there is no constitution that bans discrimination based on gender identity, but does not do so with respect to sexual orientation. This demonstrates how, in general, there is more resistance to the consolidation of the rights of trans and interse ${ }^{30}$ persons. And, also, when they do protect trans and intersex rights, it is always in a legal system that already covers protection against discrimination against lesbian, gay, and bisexual (LGB) persons.

${ }^{30}$ Although, ideally, it would be better to mention "sex characteristics" to proper protect intersex persons. 
Table 2. Classification of the Possibilities of Prohibition of Discrimination Against LGBTI by Country

\begin{tabular}{|c|c|c|c|c|}
\hline 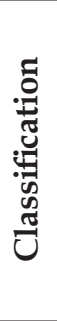 & $\begin{array}{l}\text { Prohibition of } \\
\text { Discrimination } \\
\text { Based Both } \\
\text { on Sexual } \\
\text { Orientation } \\
\text { and Gender } \\
\text { Identity }\end{array}$ & $\begin{array}{l}\text { Prohibition of } \\
\text { Discrimination } \\
\text { Based Only } \\
\text { on Sexual } \\
\text { Orientation } \\
\text { "preferencias } \\
\text { sexuales") }\end{array}$ & $\begin{array}{l}\text { Absence of } \\
\text { Prohibition of } \\
\text { Discrimination } \\
\text { Against LGBTI }\end{array}$ & $\begin{array}{l}\text { Without } \\
\text { Regulation } \\
\text { or Group } \\
\text { Specification }\end{array}$ \\
\hline 异 & $\begin{array}{l}\text { Bolivia and } \\
\text { Ecuador }\end{array}$ & Mexico & $\begin{array}{l}\text { Brazil, Colombia, } \\
\text { Guyana, } \\
\text { Paraguay*, Peru, } \\
\text { Suriname and } \\
\text { Venezuela }\end{array}$ & $\begin{array}{l}\text { Argentina, } \\
\text { Chile and } \\
\text { Uruguay }\end{array}$ \\
\hline
\end{tabular}

As can be seen, a more detailed examination of the data further demonstrates how the protection of LGBTI persons in Latin American is precarious. If the initial perception was that only three of the constitutional texts contained a clause prohibiting LGBTI discrimination ${ }^{31}$, the detailing of the data indicates that only two of these countries (Bolivia and Ecuador), which represent only $15 \%$ of those analysed, cover both sexual orientation and gender identity. This is because the Mexican Constitution chose to name only the term "sexual preferences", refraining from recognizing specific protection for trans and intersex persons.

In addition, Ecuador deserves a positive highlight. By far the most advanced and progressive constitutional text in the protection of LGBTI rights, the constitutional legislator of that country has opted to include in the list of prohibited discrimination, in article 11, section two, differential arbitrary treatment in relation to persons living with HIV (Human Immunodeficiency Virus). Although this right is not addressed exclusively to

31 The Brazilian LGBTI movement did try to include sexual orientation in the text of the constitution, although unsuccessfully. Regarding this, see: Lelis, Rafael Carrano, Marcos Felipe Lopes de Almeida, and Waleska Marcy Rosa. "Quem conta como nação? A exclusão de temáticas LGBTI nas assembleias constituintes de Brasil e Colômbia". Revista Brasileira de Políticas Públicas 9, no. 2 (2019): 83-109. http:/ / dx.doi.org/10.5102/rbpp.v9i2.6047. 
LGBTI people, it is a significant protective increase, since it has historically stigmatized the LGBTI population by associating it with the virus, which at the beginning of the epidemy was mistakenly named "the gay plague". Therefore, it is another way to protect LGBTI from discrimination.

Turning to the analysis of countries that have no provision, the Chilean, Uruguayan, and Argentine constitutions fall into a peculiar category. Whereas the fundamental law of the first two has chosen to provide for the prohibition of discrimination without indicating the possibilities (even if exemplarily) of protection, the latter abstained from any mention of anti-discrimination rights.

On the other hand, those placed in the third column present a list, many of them extensive, indicating hypotheses in which discrimination is prohibited. In all of them, without entering into the discussion of whether or not the possibilities are exhaustive, there is no mention that refers specifically to LGBTI persons. The clauses, in general, prohibit discrimination on grounds of ethnicity, age, sex, religion, political affiliation, socioeconomic status, national origin, health condition, among other reasons. It is pertinent to note that the Constitution of Guyana, which has the most extensive role, besides not including issues such as sexual orientation and gender identity, provides, in the constitutional text itself, several exceptions to the exercise of this guarantee, which ends up removing most of the norm's legal coverage.

Moreover, in the case of Paraguay, indicated with an asterisk, there is another singularity. Although article 46 of its constitutional text provides that "no discrimination is admitted", the grounds are only listed in the section on labour rights (article 88 of the Paraguayan Charter).

In sum, it is clear that Latin American constitutional law still needs to go a long way in the specific protection of one of the most basic rights of the LGBTI population: the right to non-discrimination, which is essential if all other fundamental guarantees relating to these individuals are to be achieved.

\section{Right tO CIVIL UNION}

The last of the three criteria adopted by the research refers to the possibility of civil union between couples of the same gender. In addition to being 
the most difficult to gauge among all, it is also the most controversial within the LGBTI movement itself. Thus, some reservations regarding the reason of its choice are necessary.

The possibility of civil union has been considered because it is still, in the vast majority of legal systems, a requirement for access to various rights by persons who relate in a loving and affective way, such as: inheritance, taxation, access to health, property rights, pension, and adoption, among others. Thus, denying marriage or other form of civil union to LGB means denying them access to various other essential rights in their lives. And, above all, the symbolic factor that represents the legal recognition of these relationships cannot be ignored.

Nonetheless, the demand for recognition of same gender unions as legally valid by the State is a highly controversial thematic and the positions of LGBTI activists differ. At the same time that the symbolic character of this achievement and the access to the rights it provides must be taken into account: to claim this institution for gays and lesbians means to reinforce the legitimization of this State normalizing power over sexuality, including non-heterosexual couples in the field allowed by the norm and at the same time reinforcing the exclusion of several other affective configurations.

Some authors ${ }^{32}$ classify this demand for union and, more specifically, for marriage, as a kind of assimilation of the LGBTI movement of the institutions and the rights consecrated to heterosexuals, to the detriment of advocating a deeper and structural rupture of the foundations that legitimize the system. It is again the perspective between the definition of an affirmative remedy, which would be the mere extension of the right to civil union and marriage to gays, lesbians, and bisexuals, and a transformative one, which should advocate for the dissolution of the marital institution itself and its power of legitimation/delegitimation that denies rights to individuals.

32 See: Miskolci, Richard. Teoria Queer: um aprendizado pelas diferenças. Belo Horizonte: Autêntica Editora: UFOP, Universidade Federal de Ouro Preto, 2016. And: Rios, Roger Raupp. “As uniões homossexuais e a 'família homoafetiva': o direito de família como instrumento de adaptação e conservadorismo ou a possibilidade de sua transformação e inovação". Civilistica.com 2, no. 2 (2013): 01-21. 
In this way, what was sought with the use of this criterion is a conscious claim of the right to civil union, without forgetting the necessary reservations. In Butler's words "to keep the tension alive between guarding a critical perspective and making a politically readable claim". ${ }^{33}$ That is, "to suggest a policy that incorporates a critical understanding - the only one that can be claimed as self-reflective and non-dogmatic" ${ }^{34}$. In other words, the author allows us to conjecture on how, politically, the claim for intelligibility and recognition is crucial. That is, the guarantee of rights, without which the very condition of the person is questioned. However, Butler's caveat refers to the fact that the quest for legitimacy is not excluded from the power structure and may lead to other forms of social hierarchy and a dangerous magnification of State power, thus, delegitimizing sexual practices lived out of contracts such as marriage and their presuppositions of monogamy, and, therefore, with the potential, in the words of the author, to transform "a collective delegitimation into a selective delegitimation".

Turning to the textual analysis, unlike the right to non-discrimination, a specific provision that would recognize/allow the civil union between same gender persons was not sought. It would be too naive to consider the possibility that some constitution had expressly provided for the right of homosexuals to marry. For this reason, what has been analysed is the form in which the right to marriage or to a stable union is presented in the constitutional text, that is, if the norm delimits the gender of the spouses, acting as a restriction to the constitutional right of union, excluding homosexuals from its scope of protection, or, if the clause was generic, without the demarcation of gender.

To do so, it was used a classification proposed by Virgílio Afonso da Silva, which includes three possibilities for the constitutional text: 1) no provision; 2) specific provisions regarding gender; 3) gender-neutral provisions. ${ }^{35}$ It is important to clarify: neutral provisions would be the case of no mention of the female or male gender, as when it is said that the

${ }^{33}$ Butler, Judith. "O parentesco é sempre tido como heterossexual?". Cadernos Pagu 21(2003): 219-260 at 230.

34 Ibid.

35 Silva, Virgílio Afonso da. “La unión entre personas del mismo género: ¿cuán importantes son los textos y las instituciones?". Discusiones 15, no. 2 (2014): 171-203. 
marriage will occur between "two persons". On the other hand, a genderspecific clause translates into the provision, for example, that a stable union occurs between "a man and a woman". For didactic reasons, it was decided to analyse separately the institutions of marriage and stable union.

Thus, as can be observed in the data presented in Table 3, with regard to marriage, none of the constitutional charts examined falls within the third category. Among those analysed, the constitutions of at least six countries have no disposition about marriage, or, as in the case of Peru, indicate that the matter will be regulated by law.

In this scenario, Brazil's situation is more complex to classify. The country was allocated to the first column of the table, but could also have been included in the third. This is because Article 226 of the country's Constitution states: “Art. 226. The family, the basis of society, shall enjoy special protection from the state. $\$ 1^{\circ}$ Marriage is civil and of free celebration". Thus, although there is mention of the marriage institution, it does not allude to the subjects that would integrate this union (unlike what happens in the case of a stable union). Hence, there is no way to fit as a gender-neutral reference if there is no allusion to individuals. For that reason, it was understood that it would be best to categorize it along with those who do not regulate the institution.

Besides Brazil, two other countries, among those categorized as "without provision", deserve prominence. In the case of the Mexican and Surinamese constitutional texts, although there is no actual disposition about marriage, Articles 4 and 35 (respectively) of the fundamental charter of those countries seem to suggest that the only family composition admitted would be heterosexual. However, the textual construction is open, leaving room for an interpretation that it only aims to ensure the need for isonomy between man and woman within the heterosexual relationship, as seen: "Article 351 . The family is recognized and protected. 2. Husband and wife are equal before the law"; and "Artículo $4^{\circ}$. Man and woman are equal before the law. It will protect the organization and development of family".

On the other hand, all the other constitutions establish that marriage occurs between "man and woman", recognizing only the heteronormative model of family composition. Curious is the systematics of the Ecuadorian Constitution, which in its article 67 provides that "family is recognized 
in its various types" and, soon after, in the same article, indicates that marriage is the union between man and woman. What can be deduced from this, together with the norms that regulate the stable union, is that the Fundamental Charter of Ecuador would be recognizing the status of family to single-parenting arrangements and, perhaps, other couples than just the heterosexual ones, but limiting the institution of marriage to only the traditional heteronormative construction.

Table 3. Provisions of the Constitutions on Marriage

\begin{tabular}{|c|c|c|c|}
\hline Classification & No Provision & $\begin{array}{l}\text { Gender-specific } \\
\text { provisions }\end{array}$ & $\begin{array}{l}\text { Gender- } \\
\text { neutral } \\
\text { Provisions }\end{array}$ \\
\hline Countries & $\begin{array}{l}\text { Argentina, Brazil*, } \\
\text { Chile, Guyana, Peru, } \\
\text { Suriname, Uruguay } \\
\text { and Mexico }\end{array}$ & $\begin{array}{l}\text { Bolivia, Colombia, } \\
\text { Ecuador, Paraguay } \\
\text { and Venezuela }\end{array}$ & - \\
\hline
\end{tabular}

When the analysis turns to the legal institution of stable union (or de facto union), the scenario changes slightly. As shown in Table 4, the third column, previously empty, now includes Ecuador, whose constitutional text states in its article 68 that "the monogamic stable union between two persons (...) shall have the same rights and obligations as the families constituted by marriage". With this provision, there is no possibility to argue that the Ecuadorian Constitution would not allow civil unions, through the institution of a stable union, for homosexual couples. The textual set is very clear in that marriage occurs between "man and woman" and the stable union between "persons", besides indicating that the family is recognized in its various types. The constitutional legislator intended to include the same gender couples in this possibility of union, characterizing itself as the most progressive clause in the theme among all the countries analysed.

However, the progressive thinking of the Ecuadorian system is yet limited. In addition to making it possible to extend only the stable union (and not marriage), the Constitution, in the same article 68, expressly provides that adoption can only be performed by heterosexual 
couples $^{36}$, leaving no room for a differentiated hermeneutic interpretation, which leads to a great setback in regard to the rights of LGBTI.

All other countries fall into the first two classifications and five of them expressly state that stable union occurs between men and women. Moreover, it should be noted that two countries that did not have a disposition about marriage, Brazil and Peru, explicitly indicate that this second type of union will occur between men and women.

Table 4. Disposition of the Constitutions on the Stable Union

\begin{tabular}{|c|c|c|c|}
\hline Classification & No Provision & $\begin{array}{l}\text { Gender-specific } \\
\text { provisions }\end{array}$ & $\begin{array}{l}\text { Gender- } \\
\text { neutral } \\
\text { Provisions }\end{array}$ \\
\hline Countries & $\begin{array}{l}\text { Argentina, Chile, } \\
\text { Colombia, Guyana, } \\
\text { Suriname, Uruguay } \\
\text { and Mexico }\end{array}$ & $\begin{array}{l}\text { Brazil, Bolivia, } \\
\text { Paraguay, Peru and } \\
\text { Venezuela }\end{array}$ & Ecuador \\
\hline
\end{tabular}

Thus, it is noticeable that protection of LGBTI rights, regarding the criteria of this section (which merely expects the absence of restriction with respect to civil unions), is practically nonexistent. With the exception of the Ecuadorian Constitution (and only regarding stable union), all the other charters analysed either had no provision on the matter or restricted the scope of possibilities to a heteronormative reality.

\section{Other Provisions}

As mentioned at the beginning of this section, in addition to examining the three criteria developed so far, a full reading of the constitutional texts was carried out in the search for other normative provisions concerning the LGBTI population, which could not be anticipated. In that sense, additional highlights can be made.

${ }^{36}$ The final part of article 68 of the Ecuadorian Constitution states: "the adoption will only correspond to couples of different sex". 
The first of these concerns the Bolivian Constitution, which in its article 66 consolidates the guarantee of the exercise of sexual and reproductive rights. The sexual rights category has transformed throughout history, symbolically consolidating itself as a form of protection for LGBTI rights. Although it seems to have a very principiological and indeterminate nature, it is an important textual provision that can be used to protect broadly the most diverse rights of LGBTI persons.

On the other hand, the Fundamental Charter of Ecuador was a pioneer in the Latin American context, being the only one to provide a substantive specific right to this population. In this sense, its article 66, item 9, the Charter guarantees the right of free and safe choice of sexual orientation. Without entering into the discussion about the use of the word "choice", the provision establishes an unprecedented safeguard in the constitutional law of the region. In addition, Article 83, paragraph 14, of the same document consolidates the duty of Ecuadorians to "respect and recognize" others "sexual orientation and identity".

The Ecuadorian text also sustains, in its article 21, the right to aesthetic freedom, a provision that was included because of the persistence of the trans movement in the constitutional assembly. This right is another important way of protecting the LGBTI population, but especially trans persons. This is because, by ensuring aesthetic freedom, it safeguards the possibility of persons to transgress traditionally imposed standards on females and males, particularly in relation to clothing and body appearance.

Finally, article 347, section IV, of the Ecuadorian Constitution establishes the right to sex education. Although this clause may be interpreted in such a way as to perpetuate only a heteronormative education, it is an important break with the taboo of sexuality.

Lastly, applying the same method of rules of inferences already described, it is possible to try to present a reason why the prediction of LGBTI rights appeared in the constitutions of Mexico, Ecuador, and Bolivia and not in the others. The thesis is that the provision is related to the date of enactment of the constitutional text. That is, only the most recent constitutions would present such a norm. In this case, the main variant would be the (most recent) date of the constitutional text, while the dependent variant would be the normative provision of LGBTI rights. Thus, as can be seen in Table 5, the most recent constitutions are 
those of Ecuador and Bolivia. On the other hand, the prohibition against discrimination based on "sexual preferences" in the Mexican document was introduced by an amendment only in the year 2011. Therefore, there seems to be a relation between the date of promulgation and the progressiveness of the norm, something that was already relatively easy to foresee, since the newer the text the easier it is for it to be influenced by more progressive ideals than those prevalent in previous centuries ${ }^{37}$.

Table 5. Date of Promulgation of Constitutional Texts

\begin{tabular}{ll}
\hline Countries & Date of Constitution Promulgation \\
\hline Argentina & 1853 (last reform in 1994) \\
\hline Bolivia & 2009 \\
\hline Brazil & 1988 \\
\hline Chile & 1980 \\
\hline Colombia & 1991 \\
\hline Ecuador & 2008 \\
\hline Guyana & 1980 \\
\hline Mexico & 1917 \\
\hline Paraguay & 1992 \\
\hline Peru & 1993 \\
\hline Suriname & 1987 (last reform in 1992) \\
\hline Uruguay & 1967 (last plebiscitary reform in 2004) \\
\hline Venezuela & 1999
\end{tabular}

In addition, another factor that can be pointed out, specifically in relation to the Ecuadorian reality, is the protagonism of civil society. In that country, the approval and even the remembrance of most of these provisions was due to intense lobbying work in the constitutional

${ }^{37}$ Nonetheless, it must be noted that we are currently facing a rise of extreme-right ideology throughout the world. Thus, it is hard to say that the result would be the same if the constitutions were to be voted today. 
assembly, especially by the members of the Transgender Project ${ }^{38}$, who worked directly with parliamentarians. ${ }^{39}$ However, it is possible to see that that influence has encountered certain barriers, not being able to exclude, for example, the clause of article 68, which expressly only allows adoption by heterosexual couples. Nevertheless, the Ecuadorian scenario illustrates the importance that social movements can play in norm-creation, pressing for a more dignified standard for LGBTI persons. This especial role of the social movements will be further explored in the next chapter.

\section{DeVELoping aLGBTI CONSTITUTIONALISM: THE VIEW OF THE LGBTI LATIN AMERICAN MOVEMENT ON THE CONSTITUTIONAL PROTECTION OF ITS RIGHTS}

In the previous chapter, a critical diagnosis was outlined of the current Latin American normative constitutional panorama regarding the protection of LGBTI rights. Moreover, we sought to point out the degree of (in)sufficiency of the norms found in the protection of the LGBTI population. Nevertheless, it would be too pretentious and arbitrary to label a given legal order as protective or not, based solely on the view of this researcher or merely on the literature focused on this subject. Thus, within the proposal of this work, it is essential to support the construction of a transformative constitutionalism (desde abajo), which acts in a counter-hegemonic way and from the perspective and protagonism of the LGBTI themselves. After all, who better than the victims of violence themselves to say whether they feel protected or not? Or, what should or should not be covered by the constitutional text in order to protect their main interests?

${ }^{38}$ The organization's website can be found at: http://www.proyecto-transgenero. org/. Accessed on: 01 Apr. 2018.

${ }^{39}$ Lind, Amy, and Sofía Argüello Pazmiño. “Activismo LGBTIQ* y ciudadanías sexuales en el Ecuador: Un diálogo con Elizabeth Vásquez". Revista de Ciencias Sociales 35 (2009): 97-101. 
In this sense, it is important to prioritize a bottom-up approach in the construction and interpretation of the law. Or, in the words of Santos and Rodríguez-Garavito, a "subaltern cosmopolitan legality". ${ }^{40}$ In addition to this discussion, Boaventura de Sousa Santos asserts that in order to achieve the transformation of our present model of state and society, an appropriation would be necessary of the hegemonic political instruments by those marginalized classes and groups. ${ }^{41}$ Thus, he classifies the counterhegemonic use as contrary to the dominant ideology and that, in order to sustain itself, it "needs [...] a permanent political mobilization that, to be effective, has to operate from inside out in the institutions". ${ }^{42}$ In the constitutional field, the author characterizes that such mobilization would take place in a transformative constitutionalism desde abajo, opposing to the modern Eurocentric and liberal constitutionalism. ${ }^{43}$

In this way, the perspective of subaltern cosmopolitan legality seeks to place victims in evidence, allowing them, who are excluded from the hegemonic (top-down) paradigm, to reshape institutions in order to be included and recognized, establishing a pattern that will no longer be hegemonic, but counter-hegemonic. It is to say: " subaltern cosmopolitanism calls for a conception of the legal field suitable for reconnecting law and politics and reimagining legal institutions from below". ${ }^{44}$

Moreover, such an approach also aims to overcome the liberal paradigm of individual autonomy by incorporating alternative forms of legal knowledge. That is, legal interpretations that extrapolate the usually authorized interpreters of law and that come to understand

40 Santos, Boaventura de Sousa, and César A. Rodriguez-Guaravito. "Law, Politics, and the Subaltern in Counter-hegemonic Globalization". In Law and Globalization from Below: towards a cosmopolitan legality, eds. Boaventura de Sousa Santos and César A. RodriguezGuaravito (Cambridge: Cambridge University Press, 2005), 01-26 at 5.

${ }^{41}$ Santos, Boaventura de Souza. Refundación del Estado en América Latina: Perspectivas desde una epistemología del Sur. Lima: Instituto Internacional de Derecho y Sociedad, 2010.

42 Ibid, at 60 .

43 Ibid.

${ }^{44}$ Santos, Boaventura de Sousa, and César A. Rodriguez-Guaravito. "Law, Politics, and the Subaltern in Counter-hegemonic Globalization". In Law and Globalization from Below: towards a cosmopolitan legality, eds. Boaventura de Sousa Santos and César A. RodriguezGuaravito (Cambridge: Cambridge University Press, 2005), 01-26 at 15. 
the legal field as constituted of "elements of struggles that need to be politicized before they are legalized". ${ }^{45}$

A lot of these factors were present in most of the Latin American constitutional processes. This has resulted in broadly transformative texts, especially as regards the rights of indigenous and traditional peoples, women, and the environment. However, as observed in the previous chapter, the same did not occur for the LGBTI population. And that needs to be changed through the protagonism of the affected individuals, which is illustrated in the construction of a LGBTI constitutionalism as opposed to the hegemonic heteronormative standard.

Similarly, Nancy Fraser points out that the perception of demands for justice must be analysed from the standpoint of social movements. In this sense, she affirms that the terms "redistribution" and "recognition" (this applies also to "representation") have a political reference, in addition to the philosophical one, that relates to the claims raised by political actors and social movements in the public sphere. ${ }^{46}$ Thus, it is essential to observe the opinion of the members of these movements.

It is important to note that this counter-hegemonic action should not only occur at the time of the legislative creation of the law, but also in its interpretation. In this way, an extension is proposed of the idea of a pluralist interpretation conceived by Häberle. ${ }^{47}$ The German author advocates for overcoming what he termed a "closed society of interpreters" (marked by the state monopoly of this function through judicial action) for an open society that would embrace a multiplicity of interpretive actors, beyond those traditionally authorized and legitimized. According to him, "everyone who lives in the context regulated by a norm (...) is indirectly, or even directly, an interpreter of this norm" ${ }^{48}$ Therefore, all citizens that experience or, in many cases, feel their absence, would be pre-interpreters or co-interpreters of the constitutional order.

45 Ibid, at 16.

${ }^{46}$ Fraser, Nancy. "Social Justice in the Age of Identity Politics: Redistribution, Recognition, and Participation". In Redistribution or recognition?: a political-philosophical exchange, eds. Nancy Fraser and Axel Honneth (London: Verso, 2003), 07-109.

${ }^{47}$ Häberle, Peter. Hermenêutica Constitucional: a sociedade aberta dos intérpretes da constituição: contribuição para a interpretação pluralista e "procedimental" da constituição. Porto Alegre: Sergio Antonio Fabris Editor, 2002.

48 Ibid, at 15. 
The construction of a pluralistic constitutional hermeneutics is essential for the diversification of interpretation and for the amplification of interpretative legitimacy. However, it does not seem to be enough to be characterized as a bottom-up approach. Hence, we argue that when it comes to the violation of human and fundamental rights, those who live the norm (or their absence) should not only act as co-interpreter, but as the main interpreter and the most (if not the only) legitimized for such interpretation. Thus, the State function would be to convey the interpretation of the affected individuals. And this should be not only in the arenas formally legitimized to exercise jurisdiction (through, for example, amicus curiae institute and public hearings ${ }^{49}$ or even strategic litigation), but also in their interpretation in other fields, such as in scientific, doctrinal, and political debates. That is, to hear the voice of those who really should be heard, for they are juridically and materially affected by the law.

Bearing this purpose, this chapter is dedicated to the construction of the constitutional interpretation of Latin American LGBTI movements about the protection or not of their rights by the constitutional text. Thus, making use of a self-completing survey, we sought not only to draw an ideal protective pattern (to be compared with the data collected in the previous chapter), but also to understand the perception of this movement on the current LGBTI rights scenario in Latin American constitutionalism, its causes and possible alternatives for its change.

\section{Method AND SURVEY ANALYSIS}

Once more, in order to respect the replicability rule of empirical research, a detailed description of the data collection process is required. As already mentioned, one of the objectives of this research is to allow the construction of a constitutional bottom-up interpretation, with the leading role of LGBTI people. In this sense, considering the difficulty of delimiting the population (due to several factors, such as the condition

${ }^{49}$ It is important to note that these institutional means of legitimizing judicial decisions have often been used as mere formal legitimators, since there are few instances in which magistrates actually consider what has been raised by these actors. 
of anonymity in relation to the non-heterosexual orientation or the noncisgender condition), it was considered that the best way to reach the needs of this population would be through organizations that are directly engaged in this issue. In addition, the use of organizations is even more propitious due to the profile of its members, usually more accustomed to the "legal language" owing to the experience of activism, and also, to allow a more collective and less subjective perception of what the priorities of the LGBTI interests would be, while increasing the possibility of obtaining more inclusive results, attentive to the plurality of LGBTI experiences.

Regarding the instrument used to produce the data, although the survey is more usually linked to the execution of quantitative investigations, the choice was made owing to the physical and financial limitations of this investigation. As the research cut is broad, covering thirteen countries, it would not be possible to conduct interviews with representatives of each of the organizations at their headquarters. In addition, performing video-call interviews might not be acceptable to all the organizations, or might even impair the perception of information due to connection failures. Thus, the survey proved to be the best methodological option.

For its structuring, the survey was divided into four sections, predominantly open-ended questions, to enable maximum information capture and, also, a lower degree of influence on responses. The first section aimed only at obtaining general information about the organization, such as name, country, and city of headquarters, as well as contact and e-mail. Then, in the second section, it was asked what rights the organization considered that, given their importance, should be expressly provided for in the Constitution, regardless of the reality of their own countries. A gap was provided for inclusion of up to five rights and a justification for each of them, only the inclusion of at least one right being mandatory. In the next section, the only one that had a closed answer question (the options given were only "yes" or "no"), the question was: "Is constitutional protection of LGBTI rights satisfactory in your country?". Finally, the fourth section varied according to the answer given in the third, asking: why the organization considered the protection satisfactory or not; what they believed were the reasons for the protective status; and, in cases where an unsatisfactory protection had been identified, the question of what the means of solving the problem might be. 
The organizations to which the survey was submitted were randomly selected through a Google search. Thus, to compose the sample universe, the term "LGBT organizations" was typed in the field of the Google search engine ${ }^{50}$, followed by the name of the country in respect of which the organizations were to be found. The procedure was followed for the same thirteen countries analysed in the previous chapter. The searches were carried out in November 2017, the search being always carried out in the language of the respective country, varying between Portuguese, English, Spanish, and Dutch.

For the selection of organizations, only the first two pages of results shown by the Google search engine were always taken into account, both because they are considered the most relevant results and because, from the third page on, there were usually no results consistent with the research. As Regina Facchini points out, the profile of LGBTI organizations is quite diverse (ranging from collectives, NGOs, and other forms of structuring) 51 $^{51}$ and this diversity has also proved true in the results found. Thus, all the organizations that had some form of virtual contact (e-mail, facebook etc.) and that, therefore, could receive the survey to be answered, were selected. It is important to note that access to an organization's website only, in many cases, ended up containing contacts from several others: these were also selected for submission. With the exception of Guyana, where only one organization was found, at least four organizations from each country under study were selected.

With regard to Brazil specifically, in the search following the abovementioned method, seven LGBTI organizations were found. Nevertheless, in order to obtain a broader sample of the country, a list of organizations working with the LGBTI cause in Brazil available in the "TODXS App", a mobile application created by the NGO TODXS52, was also used. In the app, in addition to the list of organizations, there is access

${ }^{50}$ LGBT was used instead of LGBTI due to the fact that the first term is still more frequent in the name of organizations.

51 Facchini, Regina. Sopa de Letrinhas?: movimento homossexual e produção de identidades coletivas nos anos 1990. Rio de Janeiro: Garamond, 2005.

${ }^{52}$ For more information on the application and the organization, access: < https:/ / www.todxs.org/ >. 
to all the Brazilian legislation that could be useful to LGBTI persons, as well as a mechanism to report of cases of homo and transphobia.

After the selection, the survey was sent to a total of 188 organizations, from which were received a total of 26 responses. Besides Chile, there were answers from at least one organization from each country. The survey was sent in English, Spanish, and Portuguese, according to the language of each country ${ }^{53}$. All the e-mails with the survey were sent in January 2018, with a deadline for response by mid-February; later, they were resubmitted in February, extending the deadline for response until early March.

For the analysis of the answers, the tripartite method of qualitative analysis of empirical documentation was again applied, as proposed by Mario Cardano. ${ }^{54}$ The segmentation followed the division of questions contained in the survey, separating the analysis into four categories: rights and justifications; the satisfactory or unsatisfactory protection in the country and the reason for this characterization; the causes of satisfactory or unsatisfactory protection; and the suggestions for overcoming the lack of protection, in the cases in which it applied. Regarding the qualification of the data, the template analysis elaborated by Nigel King ${ }^{55}$ was used again, in all cases oriented inductively (data-driven). Finally, for the individuation of the relations, both cross-classifications and an analysis of deviant cases were performed.

\section{(I) RightS AND JUSTIFICATIONS}

As already mentioned, the survey contained space to indicate up to five LGBTI rights that the organization considered essential and that should be expressly stated in the constitutional texts, each accompanied by a space to justify the reason for choosing that right. The intention was to

${ }^{53}$ Due to language limitations, those sent to Suriname organizations were written in English, not in Dutch, the official language of the country.

${ }^{54}$ Cardano, Mario. Manual de pesquisa qualitativa: a contribuição da teoria da argumentação. Petrópolis: Vozes, 2017.

${ }^{55}$ King, Nigel. “Doing Template Analysis”. In Qualitative Methods in Organizational Research: core methods and current challenges, eds. Gillian Symon and Catherine Cassel (London: SAGE Publications, 2012), 426-450. 
create an ideal parameter of protection to be compared with that found in Latin American constitutional texts. As has also been pointed out, it was mandatory to suggest only the first right, the other four being optional.

From the analysis of the answers, the filling-in of 108 different rights was verified; 57 of them in the survey from Spanish-speaking organizations, forty-four in the Portuguese, and seven in the English one. Inductively, each of the rights suggested was embedded in 20 different categories, in some cases the answer being divided into two different categories. In Table 06, it is possible to observe the frequency of appearance of each of the categories in the survey, further divided by the application language.

Table 6. Frequency of Appearance of Rights

\begin{tabular}{lllll}
\hline Right & $\begin{array}{l}\text { Spanish- } \\
\text { Speaking } \\
\text { Countries }\end{array}$ & $\begin{array}{l}\text { English- } \\
\text { Speaking } \\
\text { Countries }\end{array}$ & Brazil & Total \\
\hline Right to non-discrimination & 13 & 2 & 5 & 20 \\
\hline Right to work & 3 & 1 & 1 & 5 \\
\hline Right to a dignified life/security & 3 & - & 5 & 8 \\
\hline Equal rights and opportunities & 5 & - & 5 & 10 \\
\hline Right to gender identity & 7 & - & 7 & 14 \\
\hline $\begin{array}{l}\text { Right to marriage and civil } \\
\text { union }\end{array}$ & 9 & 2 & 4 & 15 \\
\hline Right to health & 2 & 1 & 5 & 8 \\
\hline Right to family & 4 & - & - & 4 \\
\hline $\begin{array}{l}\text { Criminalization of LGBTI- } \\
\text { phobia }\end{array}$ & 2 & - & 3 & 5 \\
\hline Right to housing & 1 & - & 1 & 2 \\
\hline Access to justice & 1 & 1 & - & 2 \\
\hline $\begin{array}{l}\text { Right to free development of } \\
\text { personality }\end{array}$ & 1 & - & - & 1 \\
\hline Right to a plural education & 3 & - & 3 & 6 \\
\hline Right to asylum & 1 & - & - & 1 \\
\hline Right to maternity/paternity/ & 1 & - & 3 & 4 \\
\hline adoption & & & & \\
\hline
\end{tabular}


Table 6. Frequency of Appearance of Rights

\begin{tabular}{lllll}
\hline Right & $\begin{array}{l}\text { Spanish- } \\
\text { Speaking } \\
\text { Countries }\end{array}$ & $\begin{array}{l}\text { English- } \\
\text { Speaking } \\
\text { Countries }\end{array}$ & Brazil & Total \\
\hline Right to political participation & 1 & - & - & 1 \\
\hline Rights of intersex persons & 1 & - & - & 1 \\
\hline $\begin{array}{l}\text { Depathologization of } \\
\text { transsexuality }\end{array}$ & - & - & 1 & 1 \\
\hline $\begin{array}{l}\text { Right to gender affirmation } \\
\text { treatment }\end{array}$ & - & - & 2 & 2 \\
\hline $\begin{array}{l}\text { Right to information about } \\
\text { sexuality }\end{array}$ & - & - & 1 & 1 \\
\hline
\end{tabular}

A quick examination of the previous table allows us to affirm that the protection currently existing in Latin American constitutions is definitely far from the ideal scenario expected by LGBTI movements. Focusing in the three most frequent rights (non-discrimination, marriage, and gender identity), it is possible to recall that only two countries guaranteed the right to non-discrimination in full; only one would open the possibility of civil union (and only through stable union and not through marriage); and none had specific provisions regarding the right to gender identity (other than the prohibition of discrimination). This shows how much these constitutional texts still need advancement for the full protection of LGBTI and their recognition as human beings and subjects of rights. Thus, these data help to advance the understanding of the problem initially raised, pointing to the confirmation of the hypothesis formulated.

For a better understanding of the reasons why organizations consider such rights to be so essential, the justifications presented for those rights with a frequency greater than 10 (in bold) have been cross-checked. In addition, we also decided to examine the justifications for the rights underlined (family rights and maternity/paternity/adoption rights) because of their proximity to (and sometimes even confusion with) the issue of marriage and civil union.

With regard to the right to non-discrimination, five groups of justifications stand out. The first characterizes this right as the basis 
for the protection of all other rights and without it one cannot have access to citizenship. A second type of argument points out that the regulation of this right by merely infra-constitutional legislation would not be sufficient for its implementation. The third category of justification is based on empirical data, pointing out that, in a survey conducted directly with the LGBTI population, this was often a right that was raised as essential. A fourth type of justification is based on the history and intensity of discrimination as well as the number of LGBTI deaths. One of the organizations stresses that in their country this kind of discrimination is closely linked to religious motivations. Finally, the fifth group of justification refers to the symbolic weight and visibility occasioned by this inclusion, as well as to the legal substrate it would provide.

The next category whose justifications have been analysed ("equality of rights and opportunities") is closely linked to the right to nondiscrimination, but these two rights have been categorized separately, since they appeared separately in several of the survey's answers. The second analysis of justifications has also given rise to five distinct groups of arguments. The first one identifies that, in order to be recognized as citizens, individuals must have all their rights respected. The second group emphasizes again empirical arguments. The third, on the other hand, emphasizes that this category includes all rights denied to LGBTI persons. From another angle, the fourth group asserts that this is one way of ensuring the inclusion of LGBTI in services provided by the State. And finally, the fifth set of justifications points out that this would be the way to remove the precariousness of LGBTI lives.

Moving forward to the analysis of the right to gender identity, two main justifications have been identified. The first one refers to the need to respect the autonomy of trans people to be able to identify themselves in the way they want and without impositions by society. The second group, on the other hand, reflects that gender identity is the gateway to the realization of all other fundamental rights for trans people, guaranteeing their dignity and mitigating their vulnerability before the State, which does not recognize them as citizens.

Still in relation to this category, two more highlights deserve to be made. The first refers to a very specific right pointed out by a Brazilian organization, which affirmed the need for "the right to serve a criminal 
sentence according to the one's gender identity and in an environment free of discrimination".

The second point concerns the procedure for rectification of documents and State-issued identity papers to correspond one's selfdefined gender identity. One of the Brazilian organizations highlighted the need for the change to take place through administrative and nonjudicial channels. This is extremely important, given the difficulty of access to justice faced by LGBTI and the slowness of judicial procedures.

Finally, the analysis of the last three selected categories brings up some reflections. A common ground between the three groups of rights (right to marriage and civil union, right to family and right to maternity, paternity, and adoption) is the importance of the normative provision of these values embracing the LGBTI population. That is, regardless of the conquest of this guarantee through the judicial system, the explicit and textual provision is essential. Such concern is extremely relevant, not only because the textual inclusion of the right has considerable symbolic value, but also because it ensures a greater amount of legal certainty for these individuals, who will no longer depend on volatile judicial interpretations.

Further analysis reveals that the categories of the right to family and the right to maternity/paternity/adoption focus their justification on the need for equality of rights and recognition of the existence of a plurality of relational arrangements. On the other hand, the arguments related to the right to marriage and to civil union are more diverse, differentiating themselves into four groups. The first one repeats the pattern already illustrated in the other analysis regarding the empirical basis, indicating that this was one of the demands of LGBTI interviewed. The second justification relates to the possibility of guaranteeing visibility to same gender relationships, taking them from the private sphere and elevating them to public life. A third answer concerns the possibility of "stabilizing" this right through its prediction in the constitutional text, meaning that it could not be revoked by the mere approval an ordinary legislation ${ }^{56}$. Lastly, the most recurrent argument refers to the rights derived from

56 Taking into consideration, of course, the amendment procedure of the legal systems that are in the scope of analysis. 
marriage or civil union, which is a necessary step in most jurisdictions to guarantee various other civil rights.

In short, it is possible to conclude that all the justifications are based on the need to recognize LGBTI persons as lives that matter and subjects of rights. They seek to realize their dignity and guarantee access to the same rights as heterosexuals and cisgenders, rights that are historically and contemporaneously denied to LGBTI.

\section{(II) THE (LACK OF) CONSTITUTIONAL PROTECTION OF LGBTI RIGHTS}

The second segment to be analysed also refers to the second section of the survey. It was asked whether the organizations considered the constitutional protection of LGBTI rights in their country satisfactory or not. In addition, they were asked to state the reasons why they characterized the protection as satisfactory or unsatisfactory. The examination of the responses indicated a broad positioning with regard to the lack of protection, with only two organizations ( $8 \%$ of the total) answering that protection was satisfactory in their country.

In view of the above panorama, it seems appropriate to start the analysis by the deviant cases. That is, the two organizations that indicated that the protection is satisfactory.

The first of the two, Rincon Perfetti Abogados, has a peculiarity: it is the only law firm in the list of surveyed organizations. It was selected not only for appearing in the search for selection of organizations, but also for being an office specialized in LGBTI rights. The organization, based in Colombia, indicates two reasons to consider the protection satisfactory: 1) constitutional interpretations would suffice; 2) the establishment by the Colombian Constitution of a "bloque de constitucionalidad".

With respect to the first reason presented, it should be noted that the precedents of the Colombian Constitutional Court (CCC) are among the most progressive of all Latin American countries regarding the guarantee of sexual rights. ${ }^{57}$ In addition, Rincón Perfetti Abogados was one of the pioneers in strategic litigation that brought the issue of LGBTI rights to

57 Ripoll, Julieta Lemaitre. “O Amor em Tempos de Cólera: Direitos LGBT na Colômbia". SUR - Revista Internacional de Direitos Humanos 6, no. 11 (2009): 79-97. 
the CCC. ${ }^{58}$ Thus, considering the history built by the organization and the really advanced precedents of the country's court, it is possible to understand the context that led to the positioning. Regarding the second motive pointed out by the office, it seems to base itself on the false assumption that protection under international law would be broad and extremely advanced. However, as already mentioned, protection in the international order is also extremely deficient and incomplete ${ }^{59}$.

On the other hand, the other organization that answered "yes" to the question, based in Argentina, points out that the LGBTI population of the country would have obtained legal recognition of their rights from the "enunciados generales" of the constitutional text. Indeed, in terms of legislation, Argentina seems to be the most advanced Latin American country in this respect ${ }^{60}$. This is owing to the fact that the LGBTI movement in the country has opted for a unique approach to strategic litigation: instead of simply claiming their rights before the judiciary, judicialization was used as a way to pressure the legislative to approve laws on the subject. ${ }^{61}$ As a result, Argentina is one of the few countries to have legislative regulations on issues crucial to the LGBTI cause, such as same-sex marriage and the right to gender identity. Nevertheless, as already stated in one of the justifications, regarding the importance of the normative constitutional provision of these rights, a legal protection based on general constitutional statements has a more precarious character, since the procedure for revocation of a non-constitutional legal norm is, generally, less onerous than that required for constitutional commands.

In the case of Argentina, there was another organization based in the country that answered the survey. Projeto Educar en la Diversidad Sexual identified the constitutional protection of the country as being unsatisfactory. As justification, they pointed out that, although there

58 Ibid.

59 See: Lelis, Rafael Carrano, and Gabriel Coutinho Galil. “Direito Internacional Monocromático: previsão e aplicação dos direitos LGBTI na ordem internacional”. Revista de Direito Internacional 15, no. 1 (2018): 278-296. http:/ / dx.doi.org/10.5102/rdi.v15i1.5087.

${ }^{60}$ Corrales, Javier. LGBT Rights and Representation in Latin America and the Caribbean: The Influence of Structure, Movements, Institutions, and Culture. University of North Carolina: LGBT Representation and Rights Initiative, 2015.

${ }^{61}$ Cardinali, Daniel Carvalho. A judicialização dos direitos LGBT no STF: limites, possibilidades e consequências. Belo Horizonte: Arraes Editores, 2018. 
have been legal advances, there are still regulatory gaps regarding issues essential to LGBTI, as in the case of the right to non-discrimination.

Turning to the cross-analysis of the motives pointed out by those who consider the protection of their country unsatisfactory, twelve different reasons have been identified. From this total, five were from Brazilian organizations, five from Spanish-speaking countries and two from English-speaking countries.

In the Brazilian scenario, the following justifications were pointed out: lack of LGBTI access to basic rights; advances in the realization of rights based only on judicial decisions or administrative measures; privileges that heterosexual and cisgender persons have in our democratic system; high rate of LGBTI deaths in Brazil; and non-criminalization of homotransphobia ${ }^{62}$.

The second point raised refers to the risks and instabilities of predominantly judicial protection. As discussed in the previous chapter, the lack of provision of specific rights in the text of the constitution, allied to the composition of conservative legislative houses not open to the theme of sexuality and gender identity, led to a commitment of activism mainly in the Judiciary, through strategic litigation. However, this approach poses a number of risks: not only that the enforcement of the right is incomplete (owing to the lack of regulation or coverage of all the nuances of the issue by judicial decisions), but it also generates greater legal uncertainty, because it depends on the interpretations promoted by a changing judiciary. In this sense, one of the Brazilian organizations stresses that the security and protection of LGBTI "depends very much on the interpretation and goodwill of the people who operate the state machine". This reflects, once again, the precariousness of the current panorama of recognition of rights to LGBTI people.

The third point raised is the structure of the oppression carried by a cisheteronormative society, in which those who deviate from the norm tend to be marginalized and undervalued. The fourth aspect, in turn, refers to the same factor that supported the initial hypothesis of insufficiency raised by this article: the dimension of the number of acts of violence against the LGBTI population.

${ }^{62}$ Answers were given before the recent judgement of the Brazilian Supreme Court on the matter of criminalization of LGBTI-phobic behaviors. 
Finally, the last point, presented by another organization, concerns the non-criminalization of homotransphobia in the Brazilian legal system. The idea of using the criminal system, a means of oppression and perpetuation of structural discrimination, to protect the interests of LGBTI is a controversial issue even among LGBTI activists and scholars. While appealing to the criminal law can convey the seductive image that LGBTI lives are suddenly of importance to society, it must be borne in mind that not only this will not alter the perception of the majority of the population about such deviant identities and sexualities, but also it will act under an extremely limited and skewed scope, which already overwhelms black persons daily in Brazil. That is to say: criminalization would only serve to imprison those whom the system already frames as transgressors before even any judgment. In this way, deep reflection is needed on its application.

Continuing the analysis, the following justifications were presented in the Spanish-language survey answers: the fact that LGBTI are mentioned only in constitutional principles (raised by a Mexican organization); the lack of access to fundamental rights that are guaranteed to heterosexuals and cisgenders; the express denial of LGBTI rights (as pointed out by Ecuadorian organizations); the complete silence of the text of the constitution regarding the rights and existence of LGBTI; and the fact that the Constitutional Court is adopting a conservative stance, interpreting the rights restrictively, denying them to LGBTI individuals (as pointed out by a Venezuelan organization) ${ }^{63}$.

Moreover, the two English-speaking organizations that answered the survey indicated that they considered the protection unsatisfactory owing to the criminalization of homosexual relations in their country and the absence of constitutional specification of the right to non-discrimination.

It is also worth mentioning a last relation between the data produced in this segment and those examined in the previous chapter. From the analysis of the constitutional texts, it was concluded that the two countries whose constitutions are most advanced in the protection of LGBTI

${ }^{63}$ In some of the justifications, the organization or the country was indicated because these are issues that were specifically pointed out in relation to a particular country and cannot in principle be generalized. It should be pointed out that only those organizations which have expressly given authorization to do so are named. 
individuals are Bolivia and Ecuador. However, none of the six organizations in these two countries that responded to the survey (two Bolivian and four Ecuadorians) considered the constitutional protection of LGBTI rights as satisfactory in their country. Thus, it is noted that even in those apparently more advanced arrangements, much progress still needs to be made.

\section{(III)THE CAUSES OFTHE CONSTITUTIONAL PROTECTIONSTATUS}

In this penultimate part, it was intended to ascertain what would be the causative factors of these two different protective statuses: satisfactory or unsatisfactory. Again, the analysis starts from the deviant cases.

The two organizations that affirmed that the constitutional protection in their country suffices have highlighted that this is caused by the very fact of the protection of human dignity. Thus, they emphasize the constitutional guarantee of the rights to equality, liberty, and protection of the family, which extend to include marriage and equal adoption. At this point, the answers do not seem to refer, properly, to the causes of sufficient protection, but to the same reasons emphasized in the previous segment. The intention with this question was to perceive which conjunctural or structural characteristics led to the absence or presence of pro-LGBTI norms in certain jurisdictions.

However, if this diagnosis was not possible with the first two responses, the cross-analysis of the other organizations (those that had indicated the lack of protection) proved to be successful. In this sense, eight different categories of raised causes stand out, which are applied, by the answers presented, to the Latin American reality as a whole. However, they are all deeply connected, and it is difficult to trace precisely what is covered by each. These are: 1) the lack of LGBTI access to the political arena; 2) the formation of conservative legislatures; 3) the lack of political will to advance on LGBTI rights; 4) the socio-cultural heteronormative origins present in Latin America; 5) the continent's religious tradition and its distortion by fundamentalism; 6) the lack of awareness of the actors of justice of issues of gender and sexuality; 7) the lack of education of the population in gender and sexuality issues; 8) the absence of dialogue between public authorities and social movements. For a complete analysis of the factors, some of them will be grouped together for a joint 
examination. In this way, we will analyse in association factors: one, two and three; factors four and five; factors six and seven; and, in isolation, the last factor pointed out.

The first three motives refer directly to the political dimension of justice and to the idea of representation. As can be seen, one of the causes of unsatisfactory protection is precisely the injustice of misrepresentation ${ }^{64}$. Thus, since LGBTI persons cannot be elected and have access to the parliament, the chances that their real interests will be taken into account are proportionately lower ${ }^{65}$. This is aggravated by the composition of eminently conservative legislative houses, whose members, in addition to not having the experience of a LGBTI person, strive not to allow the advancement of their rights. Still directly linked to this is the lack of political will, whether from the legislative or the executive, to guide LGBTI demands through public policies. Now, in a scenario in which only heterosexual and conservative individuals are elected, there are no expectations of any advance through the traditional political arenas. Thus, one can point to an institutional or structural discrimination of the LGBTI population.

The two following causes refer to the heteronormative and religious sociocultural traditions, impregnated in our continent. Although they are part of a separate group, they are directly related to the previous causes. This is because it is precisely the existence of a heteronormative cultural tradition that, to a great extent, prevents the access of LGBTI to

${ }^{64}$ In this sense, Corrales points out that by the year 2014 there had only been 15 persons in the history of the legislative in Latin American and Caribbean countries, who were openly homosexual and held positions in legislative houses at the federal level. This was restricted to the following countries: Argentina, Aruba, Brazil, Chile, Colombia, Costa Rica, Ecuador, Mexico, and Peru. See: Corrales, Javier. LGBT Rights and Representation in Latin America and the Caribbean: The Influence of Structure, Movements, Institutions, and Culture. University of North Carolina: LGBT Representation and Rights Initiative, 2015.

${ }^{65}$ In an empirical research conducted on the subject, Andrew Reynolds points to the existence of an association between the (even small) presence of openly gay lawmakers and the passing of norms that advance the rights of homosexuals, since the presence of gays in the legislature has a transformative effect on the vision and voting of their heterosexual colleagues. See: Reynolds, Andrew. "Representation and Rights: The Impact of LGBT Legislators in Comparative Perspective". American Political Science Review 107, no. 02 (2013): 259-274. 
public occupations. And it is also the great presence of religious actors in the legislative houses that ends up negatively influencing the normative production with respect to LGBTIs. What we characterize as "religious fundamentalism" is, in fact, a form of distortion of religious values to support the violation of the fundamental rights of LGBTI persons. Extremely conservative proposals have been approved based on religious arguments. ${ }^{66}$ On the other hand, the maintenance of this reality and the difficulty of altering this mentality are directly related to the next causes examined, covered by a lack of education.

As discussed, two other causes were the lack of awareness among legal practitioners about gender and sexuality issues and the lack of education of the population on the same issues. Again, one seems to be the consequence of the other, and vice versa. At this point, a key factor for the advancement in the realization of LGBTI rights stands out: education. Without issues such as gender and sexuality being addressed from basic to higher education, there is no way to promote a profound change in the understanding of the general population about LGBTI. Prejudice, often driven by ignorance, must be countered by a broader debate and an education that deconstructs, mainly, biologically and religiously unduly naturalized and crystallized concepts in our society. With respect to legal practitioners, specifically, change can be more easily initiated by including specific subjects on the issue in the curricula of law schools.

The last group of motives is based on the same premise of this chapter: the need to (re)construct the law from the bottom-up. That is, the unprotective framework in LGBTI rights is due to the lack of dialogue of public power with social movements. This is because, as already stated, it is the affected individuals who have greater legitimacy for the aid and the very creation of public policies. In this way, it is essential that both legislative, executive and judiciary turn their attention to the LGBTI movement and the organizations that represent it.

As can be seen, the lack of dialogue tends to originate from public power itself and not from social movements. On the contrary, as identified by the survey, the LGBTI movement has endeavoured, in all Latin

${ }^{66}$ Vital, Christina, and Paulo Victor Leite Lopes. Religião e Política: uma análise da atuação dos parlamentares evangélicos sobre direitos das mulheres e de LGBTs no Brasil. Rio de Janeiro: Fundação Heinrich Böll, 2012. 
American countries, to reach out and influence public power in some way, seeking that its demands be at least heard and taken into account.

\section{(IV) IN SEARCH OF ALTERNATIVES}

The last of the individualized segments for analysis sought to identify ways of overcoming the current paradigm of unsatisfactory constitutional protection. To that end, organizations were asked how they believed that insufficient protection could be addressed. As previously reported, this question was directed only to those entities that answered "no" in the question regarding the sufficiency of protection in their country. This is because there is no reason for wanting to change a reality in which LGBTI are supposed to be satisfactorily covered by the rules.

Exploring the answers given to the survey, it was identified that two main fields encompassed most of the suggestions presented: legislative interventions/changes and educational policies. More specifically, there are six groupings of solutions: 1) legislative proposals; 2) greater participation of LGBTI in politics; 3) elaboration of public policies; 4) changes in the educational model; 5) conducting research related to the problems faced by the LGBTI population; 6) strategic litigation; and 7) criminalization of LGBTI-phobia.

Regarding the legislative proposals, the need was pointed out to carry out advocacy with the Legislative Branch in order to affirm the fundamental rights of LGBTI persons, guaranteeing the status of citizens to these individuals. In addition, it was stressed the need for explicit inclusion of LGBTI rights in the constitutional text, as well as the "extensive interpretation of the principles of non-discrimination already envisaged to accommodate the protection of the LGBTI population". Directly linked to this, the need for greater participation of LGBTI in politics was presented. Although a specific form of accomplishing this objective has not been made explicit, we suggest - even if the purpose of this work does not allow us to develop the idea - an alternative to be considered: the establishment of affirmative actions (through quotas) to enable greater LGBTI representation in national congresses.

In addition to a legislative approach, the need was brought up for the executive to elaborate and implement public policies aimed at the LGBTI in order to give effect to provisions from statutes. That is to say: 
just the enactment of a law or constitutional norm is not enough, if it is not accompanied by a good public policy aiming at its effectiveness and intending to raise awareness among general public.

In this sense, one of the most effective ways to change a socio-cultural cisheteronormative context is in the restructuring of the educational system. This was pointed out by almost all organizations. A pedagogicaleducational approach is needed not only to better inform individuals about all issues related to gender identity and sexuality, but also as a way of sensitizing and humanizing future legislators, public managers, and judges. Without an interdisciplinary formation from basic to higher education, there is no way to completely change our homotransphobic reality.

Moreover, the need was pointed out to persist in strategic litigation, leading emblematic cases to the courts to set precedents that benefit the LGBTI population. However, as has already been pointed out, it should be borne in mind that the use of judicial channels presents several risks and should be used mainly as a palliative, while not obtaining satisfactory public legislation and policies.

The sixth proposal analysed is aligned with the objective of this article. One organization highlighted the need to carry out investigations to produce data about the reality lived by LGBTI persons. As already pointed out, scientific engagement in the theme is considered essential, not only to provide arguments about the need to change the current paradigm, but also to deepen knowledge about a reality that in many ways lacks more reliable information. This is what this research has been trying to do.

Finally, it was suggested by a Brazilian organization that the first step to change the current reality would be the criminalization of LGBTI-phobic practices. As already discussed, the issue of criminalization is extremely controversial, even among LGBTI, and should always be accompanied by a necessary critical insight with regard to solutions within criminal law. If criminalization is considered a way out (since it does not seem possible to rule it out a priori), one must concurrently raise the discussion about the problem of structural discrimination in the criminal justice system, as well as its use as ultima ratio, seeking to highlight what would be the legal situations that really deserve to be protected by this branch of law. Moreover, as Thula Pires points out, regarding the criminalization of 
racism, rules aimed at combating discrimination through punishment may lack effectiveness, since punitive institutions naturalize patterns of oppression and do not regard such acts as discrimination. ${ }^{67}$

\section{CONCLUSION}

In the twenty-first century, many years after the end of World War II, concentration camps are still emerging, this time specifically targeting the torture of LGBTI persons. There are still legal systems that expressly discriminate against people based on their sexual orientation and gender identity. The expression of love is still criminalized, with the death penalty or life imprisonment. In the twenty-first century, LGBTI are still raped and murdered because of their mere existence, with little or no legal protection for their defence.

Concerned with this scenario, this article has sought to contribute to the reflections about the effectiveness of justice for the LGBTI population. More specifically, the objective was to gauge and understand the scope and form of constitutional protection of the rights of LGBTI persons in the countries of South America and Mexico. Thus, the research problem questioned whether or not this protection is satisfactory.

In this sense, the theoretical framework of postwestphalian democratic justice, proposed by Nancy Fraser, was adopted as a lens for understanding the dimensions of justice and the limits and possibilities of the research. Therefore, in the first chapter, Fraser's theory was developed, exploring the economic, cultural, and political dimensions of justice and their respective levels of redistribution, recognition, and representation. In this context, it was emphasized that recognition and representation have a greater influence on the lives of LGBTI. In addition, the transformative and affirmative remedies to combat injustices were differentiated.

Later, in the second chapter, the analysis of the empirical materials began. From the study of the constitutional texts of the thirteen countries which are the object of this investigation, it was possible to draw

${ }^{67}$ Pires, Thula Rafaela de Oliveira. Criminalização do Racismo - entre política de reconhecimento e meio de legitimação do controle social dos não reconhecidos. Rio de Janeiro: Pontifícia Universidade Católica do Rio de Janeiro, Departamento de Direito, 2012. 
conclusions and partial results, advancing in answering the problem. In this sense, there was a precarious scenario regarding the protection of LGBTI rights. Only two of the constitutions investigated (the Bolivian and the Ecuadorian) had an explicit prohibition on discrimination based on both sexual orientation and gender identity. Besides these, it was verified that the Mexican Constitution foresees the prohibition of discrimination only based on sexual preferences. Concerning the constitutions, it was observed that, among those that regulate marriage, no normative text was presented in an open way (with a neutral language), limiting the institution only to heterosexual couples. From another angle, with respect to the stable union, it was identified that only the Constitution of Ecuador had an open textual construction, opening the possibility for unions between two people of the same gender.

Still in relation to the constitutional charters, it was possible to point out the Ecuadorian Constitution as the most advanced in guaranteeing LGBTI rights, followed by the Bolivian one. Both, besides having stood out positively in the analysis criteria, still have additional provisions, such as safeguarding the exercise of sexual and reproductive rights in Bolivia and the right to free and safe choice of sexual orientation in Ecuador. Also emphasized was the special participation of social movements as influencers of the construction of the Ecuadorian text. In addition, from a causal inference, a relation was drawn between the date of enactment of the constitutions and the advance in the protection of the rights of LGBTI, indicating that the more recent the statute, the more likely that the tutelage will take place satisfactorily.

Finally, the last chapter of the study was devoted to an analysis of the responses of a survey applied to several organizations that work with the LGBTI theme in Latin America, favouring the perception of the right from the bottom-up. This analysis found the existence of at least twenty different essential rights to LGBTI and that should be provisioned in the constitutional text. In comparison with the scenario outlined in chapter two, the lack of protection in the Latin American constitutional scenario was confirmed, due to the absence of normative provision of almost all the rights mentioned. In addition, $92 \%$ of the organizations that responded the survey considered the constitutional protection of LGBTI rights to be unsatisfactory in their country, with only two affirming the existence of satisfactory protection. 
Although the result is not entirely surprising, it is concerning to confirm that the one which should be a more inclusive constitutional tradition, owing to its more substantive constitutions, sometimes ignores and at other times rejects the existence of LGBTI persons. More than that: it denies LGBTI basic elements that characterize human dignity. Also disturbing is the fact that, even in countries where there is minimal legislative advance, the scenario is not more promising, given the ineffectiveness of norms and the reiteration of cisheteronormative culture.

Thus, owing to the various elements presented during the course of the study, it was possible to respond to the problem proposed by the investigation, confirming the initial hypothesis of the existence of a deficit in the constitutional protection of LGBTI rights in Latin America. Hence, the relevance of this observation is emphasized, not only as a denunciation of the current scenario, but also as a way of stimulating the engagement to overcome this situation.

However, once again, the limitations of a legal approach to the problem must be emphasized. The constitutional provision is essential and is characterized as a basic level in advancing the realization of justice for LGBTI. Nonetheless, simply filling this normative gap is not enough to completely overcome the oppression suffered by those people. The creation of constitutional laws and commandments breaks only superficially with the injustice suffered by LGBTI in their cultural dimension, at the level of recognition. Thus, because it is an affirmative remedy, the law is not successful in eliminating the dichotomies that establish discriminatory distinctions between homo and heterosexual or trans and cisgender. Nor can it effectively eliminate political injustices, for it depends too on the change of structural patterns that generate such inequality. In view of this, the need to explore other fields, such as education, is reinforced, with the potential for deeper transformation of the system that is in place to maintain oppression. And, above all, the need for a transformation from the bottom-up, characterized, always, by the protagonism and direct participation of LGBTI persons. 